Vol IV. No.1, September 2019, hlm. 75- 83

Available online at www.jurnal.una.ac.id/indeks/jmp

\title{
PENGARUH PENGGUNAAN MODEL CONTEXTUAL TEACHING AND LEARNING (CTL) TERHADAP KEMAMPUAN KONEKSI MATEMATIS SISWA
}

\author{
Elfira Rahmadani \\ Pendidikan Matematika Universitas Asahan, Jl. Jend Ahmad Yani Kisaran \\ Emai :elfira.rahmadani3@gmail.com
}

\begin{abstract}
The purpose of this study was to determine whether there is an influence in using the Contextual Teaching Learning (CTL) model on the ability of students' mathematical connections in class $X$ material MAN Asahan Academic Year 2018/2019. This type of research is a quasi experimental research design with two groups pre-test and posttest. The population in this study were all class $X$ which consisted of 8 classes. There are 2 classes of research samples, namely class X IPA-3 and $X I P A-4$, taken by cluster random sampling. In class X IPA-3 as an experimental class using the Contextual Teaching Learning (CTL) model and class X IPA-4 as a control class using the direct learning model (Direct Interaction). After learning is given, posttest is obtained with the average results of the experimental class 83.7 and the control class 70.2. $T$ test results obtained t_count $=$ $2.844>t$ table $=1.68$, it was concluded that there are significant differences in the ability of students' mathematical connections taught using the Contextual Teaching and Learning (CTL) learning model with students taught using the Direct Intructon model on the material geometry.
\end{abstract}

Keywords: Contextual Teaching LearningModel (CTL), Direct Instruction Model, Geometry

\begin{abstract}
Abstrak
Tujuan penelitian ini adalah untuk mengetahui apakah terdapat pengaruh dalam menggunakan model Contextual Teaching Learning (CTL) terhadap kemampuankoneksimatematis siswa pada materi geometri kelas X MAN Asahan Tahun Ajaran 2018/2019. Jenis penelitian adalah quasi eksperimen dengan desain penelitian two group pre-test dan posttest. Populasi dalam penelitian ini adalah seluruh kelas X yang terdiri dari 8 kelas. Sampel penelitian ada 2 kelas yaitukelas X IPA-3 dan X IPA-4 yang diambil secara cluster random sampling. Pada kelas X IPA-3 sebagai kelas eksperimen menggunakan model Contextual Teaching Learning (CTL) dan kelas X IPA-4 sebagai kelas kontrol menggunakan model pembelajaran langsung (Direct Interaction). Setelah pembelajaran selesai diberikan, diperoleh postes dengan hasil rata-rata kelas eksperimen 83,7 dan kelas kontrol 70,2. Hasil uji t diperoleh $t_{\text {hitung }}=2,844>t_{\text {tabel }}=1,68$ maka disimpulkan bahwa terdapat perbedaan yang signifikan kemampuan koneksi matematis siswa yang diajar menggunakan model pembelajaran Contextual Teaching and Learning(CTL) dengan siswa yang diajar menggunakan model pengajaran langsung (Direct Intructon) pada materi geometri.
\end{abstract}

Kata kunci: Model Contextual Teaching Learning (CTL), Model PembelajaranLangsung, KemampuanKoneksiMatematis. 
Vol IV. No.1, September 2019, hlm. 75- 83

Available online at www.jurnal.una.ac.id/indeks/jmp

\section{PENDAHULUAN}

Fungsi dan tujuan pendidikan tercantum dalam Undang-Undang Sistem Pendidikan Nasional Nomor 20 tahun 2003. Dalam undangundang tersebut dijelaskan bahwa fungsi pendidikan adalah mengembangkan kemampuan dan membentuk watak yang bermartabat dalam rangka mencerdaskan kehidupan bangsa, sedangkan tujuan dari pendidikan adalah mengembangkan potensi peserta didik agar menjadi manusia yang beriman dan bertakwa kepada Tuhan Yang Maha Esa, berakhlak mulia, sehat, berilmu, cakap, kreatif, mandiri, dan menjadi warga negara yang demokratis serta bertanggung jawab.

Berdasarkan tujuan dan fungsi pendidikan tersebut, sistem pendidikan nasional harus mampu merancang sistem pendidikan yang dapat meningkatkan mutu pendidikan itu sendiri, oleh sebab itu perlu dilakukan perbaikan-perbaikan dibidang pendidikan secara terencana, terarah, dan berkesinambungan

Tujuan pendidikan nasional bangsa Indonesia merupakan implementasi dari empat pilar pendidikan yang dicanangkan UNESCO. Empat pilar ini merupakan visi pendidikan dimasa sekarang dan masa depan yang perlu dikembangkan oleh lembaga pendidikan formal dimanapun. Keempat pilar tersebut yaitu: (1) learning to know (belajar untuk mengetahui); (2) learning to do (belajar untuk melakukan sesuatu); (3) learning to be (belajar untuk menjadi seseorang); (4) learning to live together (belajar untuk menjalani kehidupan). (dalam Trianto dkk, 2011:227).

Salah satu mata pelajaran yang menjadi sorotan dalam kurikulum 2013 yaitu matematika. Matematika juga dijadikan salah satu syarat dalam menentukan kelulusan siswa. Matematika juga merupakan pengetahuan dasar yang diperlukan untuk menunjang keberhasilan siswa dalam menempuh pendidikan yang lebih tinggi. Mengingat pentingnya peranan matematika, pemerintah telah melakukan berbagai upaya dalam rangka meningkatkan kualitas pendidikan, khususnya pendidikan matematika.

Namun, mutu pendidikan belum sesuai dengan yang diharapkan. Salah satu indikator yang menunjukkan mutu pendidikan di Indonesia cenderung rendah adalah hasil penilaian-penilaian internasional mengenai prestasi belajar siswa khususnya matematika. Badan Penelitian dan Pengembangan (Balitbang) tahun 2011 melaporkan hasil survey Trends In Internasional Mathematics And Science Study (TIMSS) pada tahun 2003 menunjukkan prestasi belajar siswa 
Vol IV. No.1, September 2019, hlm. 75- 83

Available online at www.jurnal.una.ac.id/indeks/jmp

SMP Indonesia berada pada peringkat 35 dari 46 negara. Rerata skor yang diperoleh siswa adalah 411. Namun Indonesia masih berada dibawah rata-rata untuk wilayah ASEAN. Prestasi TIMSS 2007 berada pada peringkat 36 dari 49 negara dengan skor 397, sangat memprihatinkan karena skor siswa turun dan jauh lebih rendah dibandingkan rerata skor internasional yaitu 500. Hasil lebih buruk lagi ditunjukkan oleh TIMSS 2011 yakni peringkat 39 dari 43 negara. Selain TIMSS pada Program For Internasional Students Of Assesment (PISA) juga menunjukkan bahwa prestasi belajar anak-anak Indonesia yang berusia sekitar 15 tahun masih rendah. Riset terakhir yang dilakukan oleh PISA yaitu tahun 2012 dengan menyertakan 510.000 orang siswa dari 65 negara, termasuk Indonesia. Rata-rata nilai siswa-siswi indonesia menempati urutan kedua paling bawah dari total 65 negara peserta.

Hasil TIMSS dan PISA yang menunjukkan rendahnya prestasi belajar matematika siswa tentunya disebabkan oleh banyak faktor. Rendahnya prestasi belajar matematika dapat ditinjau dari lima aspek kemampuan standar yang harus dimiliki siswa dalam belajar matematika. Lima aspek kemampuan standar tersebut secara umum dirumuskan oleh NCTM (2000: 29) yaitu kemampuan pemecahan masalah (problem solving), kemampuan penalaran (reasoning), kemampuan komunikasi (communication), kemampuan membuat koneksi (connection), dan kemampuan representasi (representation).

Kemampuan koneksi matematis memiliki kaitan erat dengan kemampuan pemecahan masalah, dimana kemampuan pemecahan masalah yang baik, tentunya akan membantu siswa untuk meningkatkan kemampuan koneksi matematikanya, begitu juga sebaliknya. NCTM (2000) mengemukakan koneksi matematika (mathematical connection) membantu siswa untuk mengembangkan perspektifnya, memandang matematika sebagai suatu bagian yang terintegrasi daripada sebagai sekumpulan topik, serta mengakui adanya relevansi dan aplikasi baik di dalam kelas maupun di luar kelas. Sumarmo (2012: 23) menyatakan bahwa kemampuan koneksi matematika adalah kemampuan seseorang dalam memperlihatkan hubungan internal daneksternal matematika,yang meliputi: koneksi antar topik matematika, koneksi dengan disiplin ilmu lain dan koneksi dengan kehidupan sehari-hari. Dengan demikian, terlihat jelas bahwa kemampuan koneksi matematis merupakan salah satu kemampuan 


\section{MATEMATICS PAEDAGOGIC}

Vol IV. No.1, September 2019, hlm. 75- 83

Available online at www.jurnal.una.ac.id/indeks/jmp

matematis yang sangat penting dalam pembelajaran matematika.

Kemampuan koneksi matematis merupakan hal yang penting untuk dikuasai siswa, namun siswa yang menguasai konsep matematis belum tentu mampu berkoneksi secara matematis. Hal ini terlihat dalam penelitian yang dilakukan oleh Lembke dan Reys (Bergeson, 2000: 38) ditemukan bahwa siswa sering mampu mendaftar konsep-konsep matematika yang terkait dengan masalah riil, tetapi hanya sedikit siswa yang mampu menjelaskan mengapa konsep tersebut digunakan dalam aplikasi itu. dilihat dari proses jawaban siswa dalam menyelesaikan permasalahan yang diberikan berikut ini:

Sebuah cermin berbentuk peresegi panjang dengan keliling $360 \mathrm{~cm}$. Perbandingan ukuran panjang dan lebar cermin tersebut adalah 3:2. Hitunglah:

a. Panjang dan lebar cermin?

b. Luas cermin?

c. Berapakah harga cermin tersebut jika harga cermin per $\mathrm{m}^{2}$ adalah Rp 80.000,00?

Jawaban siswa dari persoalan yang diberikan dapat dilihat pada gambar 1 berikut:

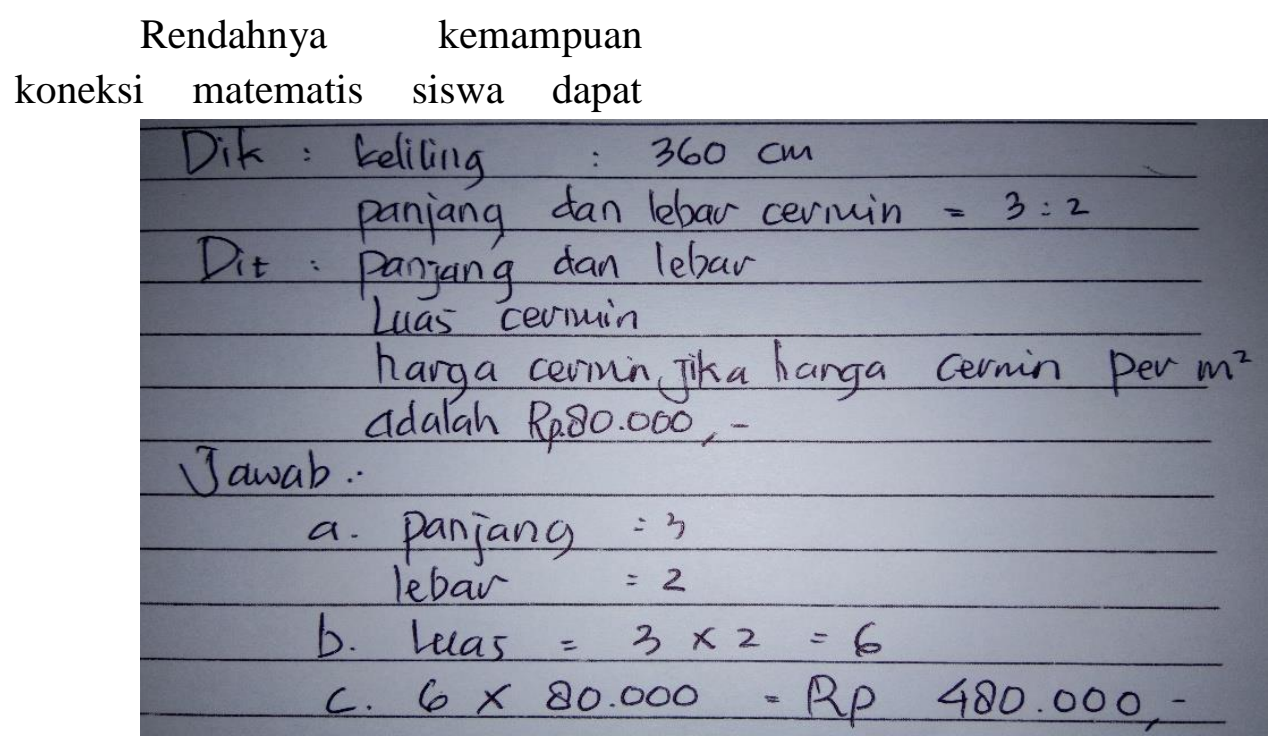

Gambar 1.1 Hasil Pekerjaan Siswa

Berdasarkan jawaban siswa tersebut menunjukkan bahwa siswa mengalami kesulitan dalam melakukan koneksi antar konsep matematika sehingga solusi yang diperoleh siswa tidak benar. Berdasarkan jawaban siswatersebut dapat dikatakan bahwa siswa belum dapat memecahkan permasalahan matematikadari soal yang diberikan. Hal ini berarti kemampuan koneksi matematis siswa masih rendah dan perlu ditingkatkan. 
Vol IV. No.1, September 2019, hlm. 75- 83

Available online at www.jurnal.una.ac.id/indeks/jmp

Selain kemampuan koneksi
matematis siswa yang rendah,
kegiatan pembelajaran juga terkesan
biasa saja tanpa menggunakan model
atau metode pembelajaran tertentu.
Pembelajaran matematika selama ini
terkesan hanya melibatkan proses
pemindahan fakta dari guru kepada
siswa semata-mata perlu dihilangkan.

Siswa hendaknya dilibatkan secara aktif didalam membina konsep dan pengetahuan yang berhubungan dengan setiap isi pelajaran yang dipelajarinya. Siswa perlu menata nalarnya, membentuk kepribadiannya, serta dapat menggunakan atau menerapkan matematika dalam kehidupannya sesuai dengan jenjang pendidikan. Untuk itu, guru harus mengubah cara penyampaian materi pembelajaran.

Untuk mengatasi masalah tersebut, guru harus senantiasa melakukan perbaikan kedepan. Perbaikan yang dapat dilakukan dapat berupa memperbaiki kurikulum, cara mengajar, model pembelajaran, memfasilitasi siswa sesuai dengan sumber belajar yang sesuai dan sebagainya. Salah satu yang dapat dilakukan adalah memperbaiki model pembelajaran. Saat ini model yang digunakan guru belum mampu mengunggah gairah siswa untuk aktif dalam kegiatan pembelajaran.

$\begin{array}{lrr}\text { Menurut } & \text { Suprijono } & (2009: 46) \\ \text { model pembelajaran } & \text { dapat } \\ \text { didefinisikan } & \text { sebagai } & \text { kerangka }\end{array}$

$\begin{array}{lll}\text { konseptual yang melukiskan } & \\ \text { prosedur } & \text { sistematis } & \text { dalam }\end{array}$ mengorganisasikan pengalaman belajar untuk mencapai tujuan belajar. Model pembelajaran mempunyai andil yang cukup besar dalam mencapai tujuan. Karena model menjadi sarana dan salah satu alat untuk mencapai tujuan, yaitu dengan materi pelajaran atau model pengajaran yang tersusun rapi dalam kurikulum pendidikan. Model pembelajaran yang tidak tepat akan menjadi penganggu kelancaran jalannya proses belajar, tercapainya tujuan pendidikan juga sangat ditentukan oleh kondisi pembelajaran yang diciptkan oleh guru di dalam kelas.

Model yang tepat untuk materi geometri adalah model Contextual Teaching and Learning (CTL). Definisi yang dikemukakan M. Hosnan (2014:267)secara bahasa kata Contextual berasal dari kata contex yang berarti "hubungan, konteks, suasana, atau keadaan". Dengan demikian, contextual diartikan "yang berhubungan dengan suasana (konteks)". Sehingga, contextual teaching and learning (CTL) dapat diartikan sebagai suatu pembelajaran yang berhubungan dengan suasana tertentu.

Model Contextual Teaching and Learning (CTL) adalah pembelajaran yang memungkinkan terjadinya proses belajar dimana siswa menggunakan pemahaman dan 
Vol IV. No.1, September 2019, hlm. 75- 83

Available online at www.jurnal.una.ac.id/indeks/jmp

kemampuan akademiknya dalam berbagai konteks dalam dan luar sekolah untuk memecahkan masalah yang bersifat simulatif ataupun nyata, baik sendiri-sendiri maupun bersama-sama.

Sanjaya (2006:255) menuturkan Contextual Teaching and Learning (CTL) adalah suatu model pembelajaran yang menekankan kepada proses keterlibatansiswa secara penuh untuk dapat menemukan materi yang dipelajari dan menghubungkannya dengan situasi kehidupan nyata sehingga mendorong siswa untuk dapat menerapkannya dalam kehidupan mereka.

Pembelajaran

Contextual

Teaching and Learning (CTL) juga merupakan suatu model pembelajaran yang fasilitas kegiatan belajar siswa untuk mencari, mengolah, dan menemukan pengalaman belajar yang lebih bersifat konkret (terkait dengan kehidupan nyata) melalui keterlibatan aktivitas siswa dalam mencoba, melakukan, dan mengalami sendiri. Dengan demikian, pembelajaran tidak sekedar dilihat dari sisi produk, akan tetapi yang terpenting adalah proses.

\section{METODE}

Jenis penelitian yang digunakan adalah metode penelitian Quasi Eksperimen, yaitu penelitian yang dimaksudkan untuk mengetahui ada tidaknya pengaruh dari sesuatu yang dikenakan pada siswa sebagai subjek penelitian. Pengaruh yang dimaksudkan adalah adanya perubahan hasil belajar siswa dengan model Contextual Teaching and Learning (CTL) dengan model pengajaran langsung (Direct Intructon) dilihat dari kemampuan koneksi matematis siswa pada tes hasil belajar.

Dalam hal ini yang menjadi populasi penelitian adalah seluruh siswa kelas X MANAsahan yang terdiri dari 11 kelas denganjumlah 396 siswa. Sampel penelitian terdiri dari dua kelas yairu kelas X IPA-3 dan X IPA-4 yang masing-masing sebagai kelas eksperimen dan kelas kontrol yang ditentukan dengan cara total sampling.

Variabel Penelitian: Pembelajaran menggunakan model Contextual Teaching and Learning (CTL); (2) Pembelajaran menggunakan model pengajaran langsung (Direct Intructon) dengan pada materi geometri. Sehingga variabel-variabel dalam penelitian ini adalah: (a) Variabel $\mathrm{X}_{1}$ adalah kemampuan koneksi matematis siswa model Contextual Teaching and Learning (CTL); (b) Variabel $\mathrm{X}_{2}$ adalah kemampuan koneksi matematis siswa model pengajaran langsung (Direct Intructon). 
Vol IV. No.1, September 2019, hlm. 75- 83

Available online at www.jurnal.una.ac.id/indeks/jmp

Untuk memperoleh data kemampuan koneksi matematis siswa maka peneliti menggunakan teknik pengumpulan data berupa tes akhir yang dilaksanakan diakhir eksperimen yang diambil dari soalsoal yang telah diuji. Bentuk tes adalah essay text.

Untuk menjawab masalah diatas peneliti melakukan uji hipotesis dalam penelitian ini dilakukan dengan uji kesamaan dua rata-rata.

\section{HASIL DAN PEMBAHASAN}

Hasil uji normalitas tes akhir kelas X IPA-3 dan kelas X IPA-4 dapat dilihat bahwa $\mathrm{L}_{0}<\mathrm{L}_{\text {tabel, }}$, dengan demikian dapat disimpulkan bahwa kedua kelas memiliki data yang berdistribusi normal.

Dari perhitungan diperoleh harga $F_{\text {hitung }}$ sebesar 1,668. Harga $\mathrm{F}_{\text {tabel }}$ pada taraf sinifikan $\alpha=0,05$ dan $\mathrm{dk}$ pada kelas X IPA-3 $=\mathrm{n}_{1-1}$ yaitu $36-1=35$, kelas X IPA-4 $=\mathrm{n}_{2}$ 1 yaitu $36-1=35$, maka dengan menggunakan daftar distribusi $\mathrm{F}$ diperoleh $\quad F_{\text {hitung }}=0,58$.Nilai signifikan tersebut lebih besar dari 0,05sehingga data kemampuan koneksi matematis siswa kedua kelompok pembelajaran berasal dari kelompok data yang homogen

Pengujian hipotesis bertujuan untuk mengetahui apakah hipotesis ini dapat diterima atau ditolak. Dari hasil pengujian persyaratan analisis data diketahui bahwa data penelitian atau data kemampuan koneksi matematis siswa merupakan data yang berdistribusi normal, homogen, sehingga pengujian hipotesis telah dapat dilakukan.

Dari hasil penelitian ditemukan bahwa nilai rata-rata kemampuan koneksi matematis siswa pada kelas X IPA-3 sebesar 83,7 berada pada kategori tinggi dan nilai rata-rata kemampuan koneksi matematis siswa kelas X IPA-4 sebesar 70,2 berada pada kategori sedang. Selanjutnya dapat dilihat dalam gambar 2.1 berikut: 


\section{MATEMATICS PAEDAGOGIC}

Vol IV. No.1, September 2019, hlm. 75- 83

Available online at www.jurnal.una.ac.id/indeks/jmp

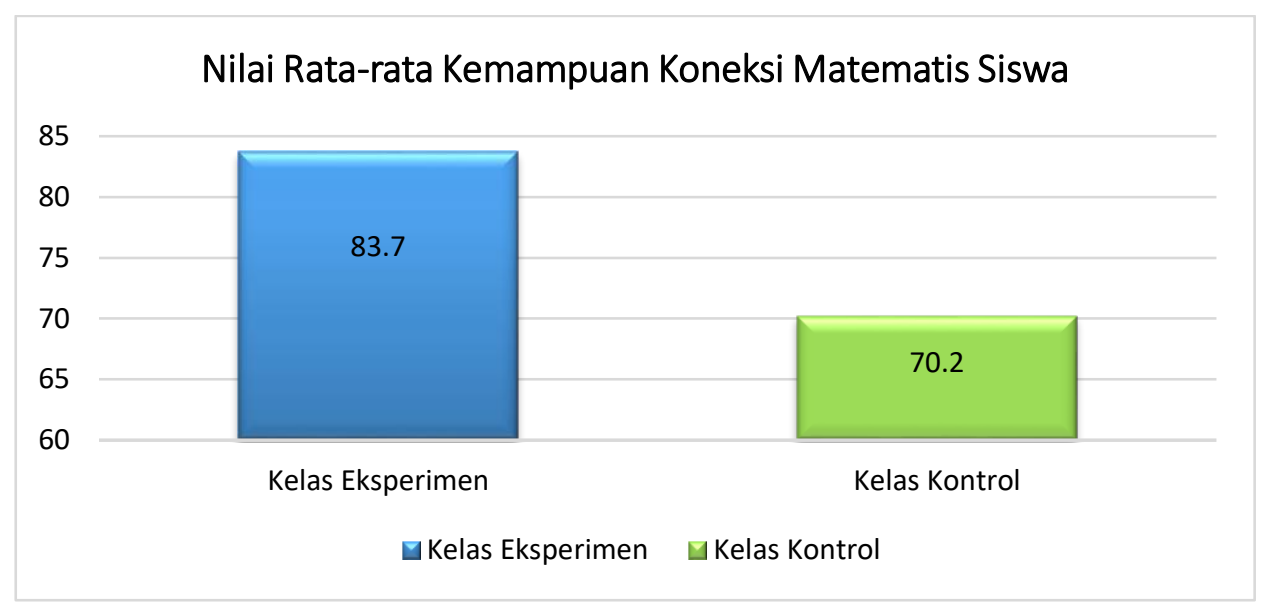

Gambar 2.1Nilai rata-rata KemampuanKoneksiMatematisSiswa

Berdasarkan hasil perhitungan juga menunjukkan bahwa thitung $(2,951)$ lebih besar dari pada nilai $\mathrm{t}_{\text {tabel }}(1,68)$ pada taraf signifikan $\alpha=$ 0,05 . Dengan demikian dapat disimpulkan bahwa penggunaan model Contextual Teaching and Learning (CTL) lebih baik dari pada model pengajaran langsung (Direct Intructon).Dari hasil perhitungan terlihat bahwa $-t_{1-\alpha}<t<$ $t_{1-\alpha}$ yaitu $(-1,68<2,884<1,68)$ sehinga dapat disimpulkan bahwa terdapat perbedaan yang signifikan kemampuan koneksi matematis siswa yang diajar menggunakan model pembelajaran Contextual Teaching and Learning(CTL) dengansiswa yang diajar menggunakan model pengajaran langsung (Direct Intructon).

\section{KESIMPULAN}

Berdasarkan penelitian yang telah dilakukan, adapun kesimpulan yang dipaparkan sebagai berikut:

1. Kemampuan koneksi matematis siswa yang diajar menggunakan Contextual Teaching and Learning (CTL) mencapai nilai rata-rata 83,7 berada pada kategori tinggi.

2. Kemampuan koneksi matematis siswa yang diajar menggunakan model pengajaran langsung (Direct Intructon) mencapai nilai rata-rata 70,2 berada kategori sedang.

3. Terdapat perbedaan kemampuan koneksi matematis siswa antara siswa yang diajar menggunakan metode contextual teaching and learning (CTL) dan siswayang diajar model pengajaran langsung (Direct Intructon). Hal ini dapat dilihat dari hasil uji t. 


\section{MATEMATICS PAEDAGOGIC}

Vol IV. No.1, September 2019, hlm. 75- 83

Available online at www.jurnal.una.ac.id/indeks/jmp

\section{DAFTAR RUJUKAN}

Bergeson, T. 2000. Teachingand Learning Mathematics: Using Research to Shift From the "Yesterday"Mind to the "Tomorrow" Mind. www.k12.wa.us.[10 November 2014].

Hosnan, M., (2014),Pendekatan Saintifik dan Kontekstual dalam Pembelajaran Abad 21. Bogor : Ghalia Indonesia, 2014

NCTM. (2000). Priciples and Standart for School Mathematics Teacher, United States of America: The National Council of Teachers of Mathematics, Inc.
Sanjaya, Wina. (2008). StrategiPembelajaran.

Bandung: KencanaPrenada Media Group.

Sumarmo, (2012), Kemampuan dan Disposisi Berpikir Logis, Kritis, dan Kreatif Matematik. Jurnal Pengajaran MIPA Vol 17 No. 1.

Suprijono. (2009). Cooperative Learning: Teori dan Aplikasi PAIKEM. Yogyakarta: Pustaka Pelajar.

Trianto., (2010), Mendesain Model Pembelajaran InovatifProgresif, Jakarta: PT. Kencana Prenada Media Group 